\title{
Human Rights: Setting the Stage for Protecting Refugee Women
}

\author{
Maryanna Schmuki
}

\begin{abstract}
This paper explores the social construction of women refugees from theperspective of the human rights regime with an eye to revealing whether the voices of refugee women are reflected. To this end the paper examines the development of women refugees as a category within human rights discourse and how this category has been bolstered by the concept of women's human rights within the last decade.

Precis

Cet article explore la construction sociale des femmes refugiees dans la perspective du regime des droits humains avec une attention particuliere portee sur la question de sa voir si la voix des femmes refugiees y est entendue. A cette fin I' article examine $I$ evolution de la notion de femme refugiee commecategorieau sein du discours sur les droits humains, et comment cette categorie a ete supportee par Ie concept de droits humains feminins dans la derniere decennie.
\end{abstract}

Protecting refugees-whether they are men, women or children, internally displaced or have crossed international borders-is the prime responsibility of the international aid community. People become refugees when fleeing their home countries precisely because they are victims, or potential victims, of human rights violations and the aid regimes exist in order to protect these rights as well as to aid victims. 1 Human rights violations, as we conceive of them in the 1990s and specific to women in wartime, have occurred as long as war itself has occurred. Until recently,

Maryanna Schmuki is a consultant for Save the Children US, an international NGO working on child-centred development. She has recently completed a Master's degree at Clark University's Program for International Development and Social Change in Worcester, Massachusetts, USA. sexual violence has been dismissed as part of the inevitable spoils of war. In an unprecedented manner, wartime rape, along with other forms of gender-specific violence, has become visible in the last decade to the extent that aid organizations have created policy to deal specifically with these issues and their effect on refugee women. This paper will explore developments within the human rights construction site, in which participants have come to recognize women's human rights, and how this has bolstered the formation of policies specifically for women refugees. I will question whether this newest portrayal of refugee women, as constructed by the human rights regime, reflects the voices of refugee women themselves and whether the answers to this have implications both for human rights practitioners and for women as refugees.

Along with the reformulation of international human rights in the late 1980s and early 1990s to include women's human rights, there has beenrecognition that women refugees are especially vulnerable to human rights violations. Refugee women often flee their homes because of sexual violence only to find the same kind of violence in their place of refuge. Often, their journeys of flight are marked by attacks by virtually all-male bandits, soldiers, border guards and sometimes even fellow male refugees. Refugee women may themselves be diverse, but they share, as women, a vulnerability both as a result of the armed conflict they are fleeing and because they are dependent on outside aid for provision of relief. Women who are internally displaced within their own country may be even more vulnerable because the conflict and abuse they are escaping from is caused by the state regime in power-the same regime who is obligated to protect them. Also, depending on the degree to which either the society from which they are fleeing, or the society in which they find refuge is organized around the presumption that a woman lacking male protection and patronage is a woman who lacks respectability, there remains a situation shared by most women in flight that makes them especially open to abuse from males.

\section{From Human Rights to Women's} Human Rights

To conceptualize human rights law, and therefore human rights violations, is to interpret rights in a very specific manner. Feminists, such as Mary W ollstonecraft in the late 1700 , pointed out very early the gendered character of the concept of "rights," even as the ideas were still being codified by thinkers like Rousseau. W ollstonecraft took on a task that is still continuing today-showing how rights in a liberal democratic tradition were created from the perspective of white, European men. When this particularnotion of rights was first reinterpreted into contemporary human rights, and then formulated by feminists into women's human rights, the potential ramifications for women refugees, as well as the category of women refugees, were great.

The contemporary notion of human rights is a specific form of rights that were codified during the reorganization of global geopolitics following W orld War II. It was during this period that the United Nations was formed

and, in 1948, the Universal Declaration of Human Rights was adopted by member nations. In the early 1980s, European and North American groups began to form NGOs to monitor human rights abuses in countries with authoritarian state regimesmany of which were propped up by European and North American governments, and enmeshed in Cold War proxy politics.

International law imposes clear obligations on governments to prohibitrape and sexual violence because such abuses violate the right, at minimum, to 
security of the person under the Intemetional Coomant on Civil and Political Rights (ICCPR). The 1966 ICCPR contains a general prohibition on gender discrimination in civil and political rights. ${ }^{2}$ Under ICCPR, the responsibility to protect refugees is in the hands of host governments who, according to a Human Rights Watch report, often show little concern and commit no resources for protecting refugee women. ${ }^{3}$ Another broad human rights document, also adopted in 1966, that can be interpreted to protect both men and women refugees is the Intermational Covenant on Ecomomic, Social and Cultural Rights. This covenant recognizes the equal right of men and women to enjoy economic, social and cultural rights." The UN Human Rights Commission waslater established to monitor compliance with these two covenants. 5

In addition to these covenants are international laws, in situations of armed conflict, to which perpetrators of persecution based on gender and sexual violence can also beheld accountable as a war crime, as a crime against humanity, or as an act of genocide.

The central and most comprehensive international legal document relating to gender-based discrimination is the Conventionion the Elimination of All Forms of Discrimination Against Women (CEDAW), which was adopted by the UN General Assembly in 1979 and which in 1994 had been ratified by 131 countries, butnot the U.S. government. 6 CEDAW has been described as an international bill of rights for women and an agenda for action by countries who ratify it. ? CEDAW has provided alegitimizing base for activists to build policy from across the board-in human rights, development, social and economic issues, and violence against women, to name a few.

With theseinstruments to work from, feminist activists, academics and lawyers began to reformulate human rights as women's human rights in the late 1980s. This created an opening for feminists inside major human rights NGOs in North America and Europe to begin documenting abuses of human rights as abuses of women's human rights and to legitimize women's human rights as a category. In 1990, Human Rights Watch established its own Women's Rights Project to monitor violence against women and gender discrimination throughout the world. This paved the way for the Women's Rights Project to later address issues of women refugees specifically.

By the early 1990s, the women's human rights movement had gained enough momentum to generate new mandates within human rights advocacy organizations, such as Amnesty International and Human Rights Watch. These mandates aimed to investigate countries whose governments have been implicated in abuse of women detainees and prisoners, governments who have imposed laws that discriminate against women, and governments who apply gender neutral laws in discriminatory ways. ${ }^{8}$ The women's human rights movement has also prompted investigation of violence against women by private actors that is tolerated or ignored by the state. ${ }^{9}$ Another importantfinding of human rights groups' investigations is that women's lack of social and economic security has compounded their vulnerability to violence and sex discrimination. ${ }^{10}$

In 1993, the UN Commission on HumanRights recognized the legitimacy of women's human rights for the first time by adopting a resolution calling for the integration of the rights of women into the human rights machinery of the United Nations. ${ }^{11}$ That same year, at the World Conference on Human Rights in Vienna, the Program of Action recognized the rights of women and girls as an inalienable, integral and indivisible part of universal human rights.

Also in 1993, the UNGeneral Assembly adopted the Declaration on Violence Against Women which recognized explicitly that states are obliged to fight specific forms of violence against women and called on governments to prevent, investigate and punish acts of violence against women. ${ }^{12}$ In 1994, the UN appointed a Special Rapporteur on Violence Against Women who was given authority to recommend measures to eliminate violence, and to work closely with other rapporteurs, independent experts and members of the Commission on Human Rights. ${ }^{13}$ The 1995 Fourth World Conference on Women in Beijing gave women from governments and NGOs worldwide a forum to address issues of women's human rights and refugee women.

There are critiques of both the human rights paradigm and the women's human rights paradigm. The feminist critiques of human rights in general helped drive the theoretical development of women's human rights. One critique of women's human rights is that it is seen as a transformation of men's rights law which is thoroughly gendered to the advantage of men. ${ }^{14}$ According to Hilary Charlesworth, with the exception of the Convention on the Rights of the Child, all general human rights instruments refer only to men. Charlesworth points out that human rights law reinforces the distinction between public and private worlds which allows the silencing of women. ${ }^{15}$ Domestic violence was construed for decades as a private matterjust as statesponsored sexual violence was seen strictly as a "family affair" of the state until recently. In terms of refugees, this kind of attitude can be seen in aid workers in the field who choose not to deal with matters of sexual violence because they see it as a "private issue" or "inevitable by-product" of conflict. ${ }^{16}$

Critiques of women's human rights point out the silencing of women among different groups of women. Radhika Coomaraswarmy shows how this kind of silencing plays out in South Asia because in Asia the rights discourse is weak, in part because it privileges free, independent women, whereas Asian women tend to be attached to their communities, castes, or ethnic groups. ${ }^{17}$ Some feminists of colour and from developing countries have asserted that the women's human rights discourse silences them by attempting to universalize a white, western view of women's rights. ${ }^{18}$ If this charge is true to any extent, the ramifications for women refugees are great. If the policies produced to protect women refugees reflect only what western feminists imagine 
refugee women need, protection may fail or be skewed toward reflecting a western imagination. But the principal opposition to acknowledging women's specific human rights has come not from the feminists, but from male-dominated governments who have seen the assertion of women's rights (such as the right of a woman to be free of domestic violence within a particular country) as an international right to be a violation of their own government's state sovereignty.

These critiques do not, however, analyze why protection forwomenrefugees may fail. As Francoise Krill notes in his analysis of sexual violence in armed conflict, "If women in real life are not always protected as they should be, it is not due to the lack of legal basis."19

From Women's Human Rights to Women Refugees

Even though UNHCR and policies for international refugees grew out of efforts to aid refugees from World War II, and despite of the fact that Eleanor Roosevelt, an advocate for women's rights, was among the leaders who established the founding universal human rights articles for the post-World War II United Nations Charter, no policies specifically for women victims of wartime sexual violence emerged during this period. This may partially explain why, for instance, it wasn't until 1992 that knowledge of the 200,000 Korean "comfort women," who were unwilling sexual conscripts of the J apanese Army during World War II, became public, although this was known by Japanese, Korean and u.s. post-war officials.2o

In 1971, during the armed conflict which produced the newly-independent state of Bangladesh, an estimated 200,000 civilian women and girls were victims of rape by Pakistani soldiers. In an episode that looked similar to the systematic rape in Bosnia in the early 1990s, Bangledeshi women were abducted into military brothels and subjected to gang assaults. At the time, the incident was appalling enough for the new government of Bangladesh to appeal for aid from the international community to deal with the aftermath, but it was not sufficient to spur the international community (governments, international agencies and nongovernmental international actors) into producing policies on sexual violence or women refugees.

In the early 1990s, while advocates for women's human rights were busy documenting the use of sexual violence for political ends and placing women's rights on international agendas, activists forrefugee women were busy creating policy within the development construction site. Advocates who lobbied for and produced policies for refugee women (such as the 1990 Policy for Refugee Women, the 1991 Guidelines on the Protection of Refugee Women and the 1995 Sexual Violence Against Refugees, and Guidelines for Prevention and Response), worked in concert with advocates who turned human rights into women's human rights. Many of the issues outlined in the policies are women's human rights issues, and they gain their legal robustness through the backing of the human rights instruments examined above.

One of the main organizational goals of the advocates and formulators of the 1990 Policy on Refugee Women is to provide protection appropriate to refugee women's specific needs. 21 Policy objectives include ensuring that protection and legal rights of refugee women are understood and responded to.22 The Guidelines on the Protection of Refugee Women elaborate on the causes for physicalinsecurity of women refugees and on ways for staff to become more aware of physical and sexual attacks during flight, sexual attacks in the country of asylum, spouse and child abuse, military violence and forced recruitment into military operations, sexual exploitation and prostitution, physical protection during repatriation, and the difficulties of prosecuting offenders.23 The guidelines also suggest program interventions to dea with these problems. They include recommendations to: provide trained staff (including women);
- train local security in the countries of asylum;

- provide culturally appropriate

- counselling; provide emergency relocation ifnec

- essary;

encourage formation of internal camp legal processes; and

- educate refugee women, men and aid workers of women's rights under national and international law.24

Because the Guidelines for Sexual Violence against Refugees were meant to create awareness and sensitivity about the needs of refugees who have been subject to sexual violence, they inherently address women's human rights as protection issues and thus see the readers and users of the guidelines as "protectors". The Guidelines elaborate and suggest a range of measures to prevent sexual violence. These measures intend to:

ensure the physical design and loca tion of the camps enhance physical

- security;

provide security patrols by local police and refugees; install fencing around the camps; identify and

promote an alternative

to living in camps;

initiate inter-agency meetings between UNHCR, other relief organizations, refugees and government officials to develop a plan to prevent sexual - violence; and

assign to the camps a greater number of female protection officers, field interpreters, doctors, health workers and counsellors. 25

The 1996-97 UN High Commissioner for Refugees, Sadako Ogata, and the holder of the recently-created post Special Rapporteur on Violence against Women for the UN Commission on Human Rights, Radhika Coomaraswamy, have recognized sexual violence against women refugees as a global outrage.

There are many reasons why rape and sexual violence are so common in refugee situations that deepen, complicate and resist the standard image of rape as inevitable in war. As human rights NGOs have begun to document in the early 1990s, rape and other forms of 
sexual violence are often used as a tool of political repression. ${ }^{26}$ Rape has sometimes been mischaracterized and dismissed by military and political leaders (those who have the power to stop it), when it is alleged within their own ranks, as committed by non-state sanctioned private actors. ${ }^{27}$ In other cases, government officials have routinely accused enemy governments of complicity in wartime rape. U.S. and European governments accused the Japanese and German governments of such complicity in World War $\mathrm{II}^{28}$ but have been lonth to admit that their own military personnel mightbeengaging in rape in ways that were encouraged or ignored by their superiors.

In its investigations on rape as a tool of war, Humen Rights Watch found that rape had been used as a tactical weapon to terroribe or "ethrically cleanse" communities, as a tool in enforcing hostile occupations, a means of conquering or seeking revengeagainst the enemy, and as a means of payment for mercenary soldiers. Rape is also used to punish women suspected of beingsympathetic to the opposition. 29 In some cases, rape is used by combatants or other statesanctioned individuals to inflict shame upon their victims, or their victims' families and communities. Sexual violence is construed and manipulated by these state actors as a profound offence against community or individual honour which many times is based on nationality or ethnicity.

Rape and sexual violence in particular are a political tool used by states in turning people (men, women and children) into refugess, and discouraging refugees from returning home. This is the basiclogic for using rape as a tool for the "ethnic cleansing" in Bosnia. "Rapes spread fear and induce the flight of refugees; rapes humiliate, demoralize, and deatroy not only the victim but also her family and community; and rapes etifle any wish to return," comments Alexandra Stiglmayer, aGerman joumalist who documented the systematic use of rape in the war in the former Yugoslavia for the book Mass Rope: The War against Women in BosniaHerzegovina. ${ }^{30}$
The use of rape and other forms of sexual violence for "ethnic cleansing" or other political motives, which turn people into refugees, is different than sexual violence against people who are already refugees, although this too can be politically motivated. Human Rights Watch documented the rapes of Somali refugees in camps of Northeastern Kenya in 1993. This report attributed nearly all the rapes occurring in the camps to shiftas, i.e., well-armed bandits who sometimes joined forces with Somali militia to launch raids across the borders into the camps in search of money, food and women. ${ }^{31}$ Analysts speculate that the shiftas are ethnic Somalis residing in Kenya who make a living robbing local residents. ${ }^{32}$ Some relief workers speculate that they might berefugees who take up arms during the nights to terrorize fellow refugees. ${ }^{33}$

The human rights regime has a specific advocacy, monitoting and educational role to play in protecting and assisting refugee women. The work of feminist-conscious NGOs, like Amnesty International and Human Rights Watch, have solidified "refugee women" as a legitimate category of analysis in the larger realm of human rights work. Human Rights Watch has made several recommendations to UNHCR which echo the recommendations made in the Guidelines for Refugee Women and the Guidelines against Sexual Violence. They have also recommended actions for host governments to:

- ensure that national laws against sexual violence are enforced in refugee camps and spontaneous settlements;

- facilitate prevention of sexual violence against refugee women through investigating incidents and assigning female police officers to camps and border points;

- take steps to ensure that asylum adjudicators recognize gender-based persecution; and

- train adjudicators to interview female asylum applicants with sensitivity. ${ }^{34}$

What Human Rights Watch found in post-1994 Rwanda, which was summarized in its resultant report, Shattered
Lives: Sexual Violence during the Rwandan Genocide and its Aftermath, was that despite the various proclamations made by the UN Human Rights Commission on women's human rights, the UN Human Rights Field Operation in Rwanda has no systematic focus to address issues specific to women. ${ }^{35}$

\section{International War Crimes Tribunals}

One way to redress the horrific sexual violence committed in the name of war, and was used to carry out state-sponsored agendas in the former Yugoslavia and Rwanda, is through the International War Crimes Tribunals. For the first time in history, the International Criminal Tribunal for the Former Yugoslavia, established by the UN Security Council in May of 1993, prosecuted soldiersfor rape as a warcrime. ${ }^{36}$ The Prosecutor's Office has stated its commitment to public recognition of sexual violence against women during the war in Bosnia. ${ }^{37}$ Even with this newfound commitment to addressing rape as a war crime, there are practical problems with prosecuting offenders. Because anonymity of witnesses is not guaranteed, and because many suspects as well as some who have been indicted remain at large, it is extremely difficult to protect women witnesses. Women are prepared to testify, but the Tribunal can only offer protection in the Netherlands where the trials are taking place. When the women return to Bosnia, they fear retribution because many suspected perpetrators remain in positions of power in Bosnia. ${ }^{38}$

In late 1994, the UNSecurity Council created the International Criminal Tribunal for Rwanda, and in 1996, the Tribunal established a Sexual Assault Committee to coordinate investigation of gender-based violence. The aim of the committee is to address strategic, legal and methodological questions in prosecuting crimes involving sexual violence. ${ }^{39}$ Within the overall aid program for reconstruction in Rwanda, very little aid is earmarked specifically for genderrelated issues. Despite the U.S. $\$ 19 \mathrm{mil}$ lion in aid to the Rwandan judiciary, in 1996, there were no programs designed 
to enhance the capacity of Rwandan police to investigate gender-based crimes including sexual violence during the genocide.40

\section{Asylum and Women Refugees}

One area where the manifestations of refugee and human rights discourses and policy have had a tangible impact on women refugees is in asylum cases worldwide. Under the Universal Declaration of Human Rights, all refugees have a fundamental right to seek and enjoy refuge from persecution or war. Until recently, the definition ofrefugees in the 1951 Convention has not been contested in terms of gender, even though many refugee women flee due to genderbased persecution or sexual violence.41 UNHCR's policies on refugee women encourage host countries to consider these factors in their regulations on allowing women refugees asylum. Currently, the United States and Canada are the only developed nations to integrate gender into refugee policies.42 But this does not ensure that adjudicators will recognize these issues, and women refugees continue to face great difficulty in attaining refugee status based on sexual violence.

The procedure in many countries is insensitive and sometimes hostile toward women seeking asylum after rape or sexual violence. In this situation, refugees are required to describe their experiences to adjudicators. Refugee women are often reluctant to relate their experiences, especially if the adjudicators are men. Adjudicators have tended to dismiss accounts of sexual violence and rape by female asylum-seekers as personal or cultural harms which do not qualify as political persecution. Adjudicators have also excluded women with gender-related claims because they do not qualify as a "particular social group" in the 1951 Convention definition.43 Women who have become targets of sexual violence because of a male relative's political activities have a even more difficult time making claims to asylum. 44

UNHCR has interpreted the 1951 Convention definition to include women as a particular social group, but the international community is slow to follow. In the mid 1980s, UNHCR started its Women at Risk program to encourage developed countries to accept women refugees identified by UNHCR as having experienced severe trauma. Three countries, Canada, New Zealand and Australia have accepted women refugees under this program, and other countries accept women refugees under their standard asylum laws.45 Women resettled through this program are very few in number. They experience other hardships once they are resettled because they typically have no knowledge of the new language and culture, have no family in their new home, and do not have skills to find jobs in industrialized countries.46

UNHCR has also resettled women refugees in other camps in cases where they have been raped or sexually abused in camps. In the camps for Somali refugees in Northeastern Kenya, UNHCR initiated a transfer system in which women could apply to move to camps along the coast, away from the Somali border where raids were taking place in 1993. This helped a few women but also caused some problems. Some women who requested a transfer had to wait so long before moving that they were assaulted again before they were transferred.47 There were also a few cases of false claims for camp transfers and resettlement to a developed country, in which women saw a tale of rape as a ticket out of the refugee camp. Binaifer Nowrojee of Human Rights Watch commented:

Refugee women build this myth of what it means to be resettled and try to get out of the camps. They have no idea of what it really means to be picked up and sent to Sweden on their own. Camps can be bad but maybe it's better to stay.48

Conclusion

The human rights instruments developed in the last decade for women, and specifically for women refugees set the stage internationally for protecting refugee women. What still remains to be seen is how these instruments and im ages help or hinder the process of women refugees returning to normalcy-or shedding their refugee skin. The human rights constructions predominant in the contemporary aid arena tend to reflect western cultural values and western epistemology as well as operate in accordance with a western institutional form. This may set the stage for protection but also act to hinder the process of rehabilitation rooted in cultural and institutional values of post-war societies. •

\section{Notes}

1. This paper is a chapter excerpted from my Master's thesis entitled "Shedding Their Refugee Skin: Constructions of Refugee Women and International Aid Regimes" (Clark University, Worcester Massachusetts, 1997), which explores four areas of knowledge production as regimes of aid. The areas-human rights, development and humanitarian aid, academia and international news media-are referred to as construction sites and come together to make up the overall system of relief to refugees.

2. Christine M. Cervenak, "Promoting Inequality: Gender-Based Discrimination in UNRWA's Approach to Palestine Refugee Status," Human Rights Quarterly 16 (1994): 341-43.

3. Human Rights Watch, Global Report on Women' sHuman Rights (New York: Human Rights Watch, 1995), 103.

4. Cervenak, "Promoting Inequality," 341 43.

5. Rebecca J. Cook, "State Accountability Under the Women's Convention," in Human Rights of Women: National and International Perspectives, edited by RebeccaJ. Cook (Philadelphia: University of Pennsylvania Press, 1994), 231.

6. Human Rights of Women, Appendix A, 573 86. 7. Cervenak, "Promoting Inequality,"

340. 8. Human Rights Watch, Global Report on Women's Human Rights, xiv-xv.

9. Ibid., xv. 10. Ibid., xv.

11. Ibid., xvii.

12. Ibid., xviii.

13. Ibid., xviii.

Women's

14. Human Rights of Women; and

Rights, Human Rights: International Feminist Perspectives, edited by Julie Peters and Andrea Wolper (New York; London: Routledge, 1995) 
15. For a detailed analysis of transforming men's rights to women's rights, see Hilary Charlesworth, "What are 'Women's International Human Rights?'," in Human Rights of Women, 68-76

16. Human Rights Watch, Global Report on Women's Human Rights, 106.

17. RadhikaCoomaraswamy, "To Bellow like a Cow: Women, Ethnicity, and the Dis course of Rights," in Human Rights of Women, 39-57.

18. Hilary Charlesworth, "What are 'Women's International Human Rights?"' in Human Rights of Women, 62-63.

19. Quoted from Joan Fitzpatrick, "The Use of International Human Rights Norms to Combat Violence Against Women," in Human Rights of Women, 546.

20. For more information on the Korean comfort women, see "Japan: Small Comfortfor Comfort Women," Ms. Magazine (MarchApril 1992).

21. UNHCR, Policy on Refugee Women Geneva:

UNHCR, 1990),7. 22. Ibid., 8. 23. UNHCR, Guidelines on the Protection ofRefu gee Women (Geneva: UNHCR, 1991), 2932. 24. Ibid., 32-35. 25. UNHCR, Sexual Violence against Refugees:

Guidelines on Prevention and Response (Ge
26. Susan ForbesMartin,Refugee Women (London; Atlantic Highlands, NJ: Zed Books, 1992), 17.

27. Human Rights Watch, Global Report on Women's Human Rights, 1.

28. Susan Brownmiller,Against Our Will: Men, Women and Rape (New York: Simon and Schuster, 1975).

29. Human Rights Watch, Global Report on Women's Human Rights, 1-3.

30. Alaxandra Stiglmayer, Mass Rape: The War against Women in BosniaHerzegovina (Lincoln:UniversityofNebraskaPress, 1994), 85. UnversityorNebraskaPress, 1994),

31. Human Rights Watch, discussion paper 5, "Seeking Refuge, Finding Terror: The Widespread Rape of Somali Women Refu gees in Northeastern Kenya," (1993),9.

32. Ibid., 5 .

33. Ibid., 6.

34. Human Rights Watch, Global Report on Women's Human Rights, 137-39.

35. Binaifer Nowrojee, Shattered Lives: Sexual Violence during the Rwanda Genocide and Its Aftermath, edited by Dorothy Q. Thomas and Janet Fleischman (New York: Human Rights Watch, 1996),6.

36. Theodor Meron, "Answering for War Crimes, Lessons from the Balkans," Foreign Affairs Gan./Feb. 1997): 2
37. From "Rape as a Crime against Humanity," International Center for War and Peace Reporting: Tribunal 6 (Nov./Dec. 1996) (web document)

38. Ibid.

39. Nowrojee, Shattered Lives, 5.

40. Ibid., 6.

41. For a detailed discussion of how the 1951 Convention could be interpreted as condoning women refugees as a "particular social group," see Jacqueline Greatbatch, "The Gender Difference: Feminist Critiques of Refugee Discourse," International Journal of Refugee Law I, no. 4 (1989).

2. From UNHCR Website, Issues section, "Women," March, 1997.

43. Human Rights Watch, Global Report on Women's Human Rights, 107. 44. Forbes

Martin, Refugee Women, 24. 45. Audrey

Macklin, "Refugee Women and the Imperative of Categories," Human Rights Quarterly 17 (1996). 46. Forbes Martin,

Refugee Women, 82. 47. Human Rights Watch,

Discussion paper,

"Protection in the Decade of Voluntary Repatriation," (1996), 20.

48. Interview, March 18, 1997, Cambridge, Massachusetts. c.J

\section{So That Russia be "Saved" Anti-Jewish Violence in Russia: Its Roots and Consequences}

By Tanya Basok and Alexander Benifand

Toronto: York Lanes Press, 1993; ISBN 1-55014-010-8; 8.5x11 61p; CDN $\$ 9.95$

The growing popularity of ultra-nationalism and neo-Nazism in Europe and to some extent in North America is truly alarming, and this publication offers a perceptive analysis of the political trends in Russia and their implications for Russian Jews. It provides an historical analysis of anti-Jewish violence in Russia and poses an important question: can those conditions which resulted in anti-Jewish pogroms at the turn of the century re-emerge today?

Dr. Basok and Dr. Benifand argue in this occasional paper that there is a number of clear indications of the popularity of the anti-Semitic and ultra-nationalist ideas not only among the masses and nationalist organizations but in the government as well.

Many of those who have been impoverished as a result of the "shock therapy" or who have grown extremely disillusioned with Yeltsin's reform policies, have become attracted to the solutions such as: getting rid of ethnic minorities, especially Jews, territorial expansion of the Russian federation to include the former Soviet republics, the extension of the Russian sphere of influence in Europe and Central Asia, protection of Russian lands (e.g., the Kurile Islands) and the curbing of ethnic nationalism within the Russian federation. Basok and Benifand's insightful analysis is an excellent attempt to understand the rise of ultra-nationalism in Russia.

\section{Available from:}

Centre for Refugee Studies

Fax: (416) 736-5837 • Email: refuge@yorku.ca 